\title{
Strategies to Reduce Nitrate Leaching under Furrow Irrigation
}

\author{
A. A. Siyal and A. G. Siyal
}

\begin{abstract}
Contamination of groundwater is a great concern in many irrigated areas of the world. In irrigated areas of world, about $90 \%$ of land is irrigated with furrow irrigation method. It is said to be water use efficient method than the conventional methods but is said to be capable of leaching large quantities of nitrogen to the groundwater. It is said that about $40 \%$ of the nitrogen applied percolate below the vadose zone of a clay loam soil which can even more leach from sandy soils. HYDRUS-2D model was used to analyse different fertilizer placement strategies in the furrow in order to reduce nitrogen leaching from a furrows prepared in different soil textures. Strategies of soil management included controlled or normal $\left(S_{n}\right)$, compacting furrow bottom $\left(S_{c}\right)$ and covering bottom of furrow with plastic sheet $\left(S_{p}\right)$. Soils used for analysis consisted, sandy loam, loam and clay. Considered placements of fertilizer included fertilizer at the sides and bottom of furrow $\left(P_{1}\right)$ near ridge the ridge top $\left(P_{2}\right)$. Results of simulations obtained with HYDRUS showed that for the considered soil textures $25 \%$ to $60 \%$ water can be saved $S_{c}$, which can further be enhanced from $50 \%$ to $95 \%$ using $S_{p}$. Simulated results revealed that $15 \%$ to $99 \%$ nitrogen leaching can be reduced by using fertilizer placement $P_{2}$. About $10 \%$ to $98 \%$ reduction in nitrogen leaching can be achieved if we adopt soil management strategies reported in this study.
\end{abstract}

Index Terms-HYDRUS-2D, leaching, contamination, nitrogens, groundwater, furrow.

\section{INTRODUCTION}

Groundwater quality in irrigated areas of world is vulnerable due to leaching of nitrates due to agricultural practices. Nitrogen is an element which is usually used in fertilizers for the vigorous plant growth and more crop yield. However, when it leaches below the vadose zone it not only compels farmers to pay more but also it pollutes groundwater and creates an environmental issue [1]. Nitrogen is highly solvable and movable ion hence is susceptible to leaching below root zone with percolating water [2]. Traditional and wasteful irrigation methods and unnecessary fertilizer applications are usually said to be responsible for the nitrates in the shallow groundwater in higher concentration [3] and [4]. Nitrate concentration above maximum allowable level i.e. $10 \mathrm{mg}^{-1}$ or $10 \mathrm{ppm}$ is usually considered fatal for human infants [5]. If the nitrate level in the water is higher it may affect other animals also [6].

In irrigated agriculture, furrow is widely used method of irrigation [7]. It is said to be a major source of nitrate

Manuscript received January 22, 2013; revised March 21, 2013.

The authors are with Department of Land and Water Management, Faculty of Agricultural Engineering, Sindh Agriculture University, Tandojam, Pakistan (email: siyal@yahoo.com). leaching and contamination of groundwater [8]. Due to low irrigation efficiency of conventional surface irrigation methods [9], alternate or partial furrow irrigation is considered for water saving and reducing of nitrate percolation to the groundwater. But crop yield losses are reported with alternate furrow irrigation method [10]. Therefore, there is dire need for research on the strategies which would optimise fertilizer and efficiency of water use and thus minimise the menace of nitrate percolation from vadoze zone to the groundwater.

In Pakistan, nitrogen is usually broadcasted manually only on moist areas of furrow viz. bed and sides. As a result, nitrogen percolates with water before it is extracted by crop. Hence, placement of fertilizer near ridge, on both sides of furrow is preferred [11] so that it does not come on the way of the percolating water. Thus, simulations of nitrogen leaching under current and the proposed fertilizer placements [12] were conducted in order to optimise fertilizer use efficiency. Also in this study different soil management strategies were tested in order to save water and reduce fertilizer nitrogen leaching under different soil textures. The soil textures used in simulations included sandy loam, loam and clay soil.

Modelling is said to be easy and cheap method which saves time, energy and cost [13]. The HYDRUS model is commonly used for simulation of movement of water and solute in the soil unsaturated zone. This model is used to find amount of nitrogen capable of leaching from furrow system when different depths of water are applied. In this study HYDRUS-2D was run to simulate movement of water and solute from the furrows so as to optimise water and fertilizer use in furrow system. The aim of the present work was to save water and maximize fertilizer retention in soil under different soil textures.

\section{Materials AND MethodS}

\section{A. Soil Hydraulic Properties}

A flow domain with $100 \mathrm{~cm}$ width and $100 \mathrm{~cm}$ depth was used. The soil hydraulic properties of textures taken into account in the study were defined using van GenuchtenMualem hydraulic model. The parameters of the considered soil textures in the study were taken from Carsel and Parish, available in the HYDRUS2D soil catalogue. Soil parameters considered in the study are shown in Table I.

\section{B. Initial and Boundary Conditions}

The initial conditions were quantified as soil water potential. Matric potential was set -50 to -30 for sandy loam, for a loam soil, -200 to $-300 \mathrm{~cm}$ and for clay soil it was 
fixed as -6000 to $-4000 \mathrm{~cm}$. The soil matric potential was allocated to all nodes such that that it decreased linearly with soil depth. The water flow and nitrogen transport boundary conditions used in are shown in Fig. 1.

TABLE I: TEXTURE AND HYDRAULIC PARAMETERS OF SOIL

\begin{tabular}{|lcccccc|}
\hline Soil $\begin{array}{l}\text { Soil hydraulic parameters } \\
\text { texture }\end{array}$ & $\begin{array}{c}\theta_{r} \\
\mathrm{~cm}^{3} \mathrm{~cm}^{-3}\end{array}$ & $\begin{array}{c}\theta_{s} \\
\mathrm{~cm}^{3} \mathrm{~cm}^{-3}\end{array}$ & $\begin{array}{c}K_{s} \\
\mathrm{~cm} \mathrm{~d}^{-1}\end{array}$ & $\begin{array}{c}\alpha \\
\mathrm{cm}^{-1}\end{array}$ & $n$ & $\ell$ \\
\hline $\begin{array}{l}\text { Sandy } \\
\text { Loamy }\end{array}$ & 0.070 & 0.40 & 4.45 & 0.076 & 1.82 & 0.5 \\
\hline Loamy & 0.074 & 0.42 & 1.06 & 0.035 & 1.46 & 0.5 \\
\hline Clay & 0.069 & 0.39 & 0.30 & 0.007 & 1.08 & 0.5 \\
\hline
\end{tabular}

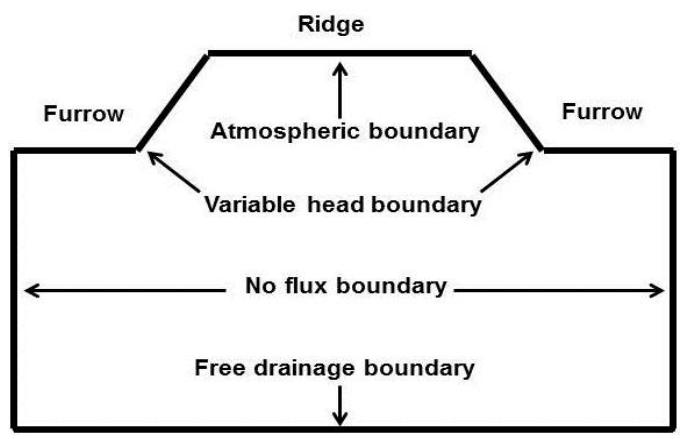

Fig. 1. Flow domain with boundary conditions adopted in the simulations

No flux condition was set on both sides of domain. Atmospheric boundary condition with a continuous potential rate of $0.014 \mathrm{~cm} \mathrm{~h}^{-1}$ was set at the surface and at the un-flooded sides of the ridge.

The both sides along with bottom of the furrow were set as variable head boundary condition. The concentration of upper soil layer was fixed equal to $12.5 \mathrm{mg} / \mathrm{cm}^{3}(\sim 150 \mathrm{~kg} \mathrm{~N}$ $\left.\mathrm{ha}^{-1}\right)$. The irrigation water was considered nitrogen free. Longitudinal dispersivity $\left(\varepsilon_{\mathrm{L}}\right)$ was taken as $10 \mathrm{~cm}$. The molecular diffusion of nitrogen was completely ignored in simulations.

\section{Soil Management and Fertilizer Applications}

Fertilizer placements considered in the present study are shown in Fig. 2. Fertilizer at the rate of $12.5 \mathrm{mg} / \mathrm{cm}^{3}$ added in the top $1 \mathrm{~cm}$ of soil. Three soil management strategies were also used to improve the irrigation efficiency and decrease nitrogen leaching. Soil at the furrow bottom was firmed in case $S_{c}$, as a result the hydraulic conductivity of the upper layer decreased to $1 / 5^{\text {th }}$ of the initial. For case $S_{p}$ no flux boundary condition at the bottom of the furrow was assumed. The HYDRUS was executed in all simulations for 120 hours.
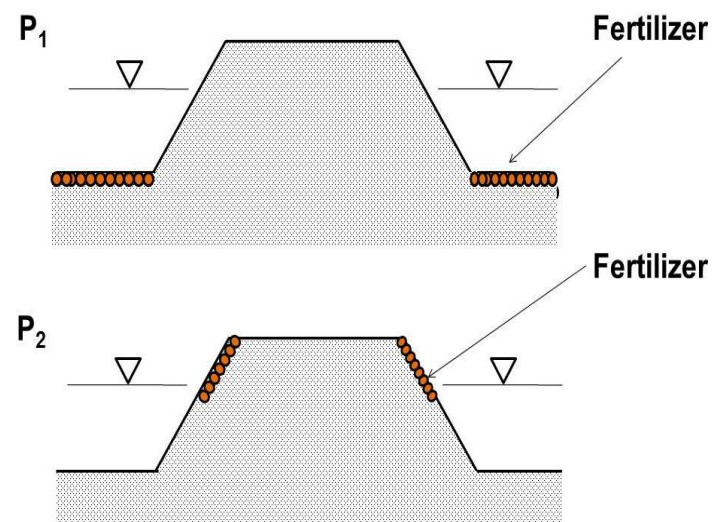

Fig. 2. Sketch of fertilizer placements considered in the study

\section{RESUltS AND DisCUSSIONS}

\section{A. Water Flux and Soil Moisture Content}

Water fluxes $\left(\mathrm{cm}^{2} \mathrm{~h}^{-1}\right)$ draining out of the bottom of the flow domain against time for different soil textures when subjected with different soil management strategies are shown in Fig.3.
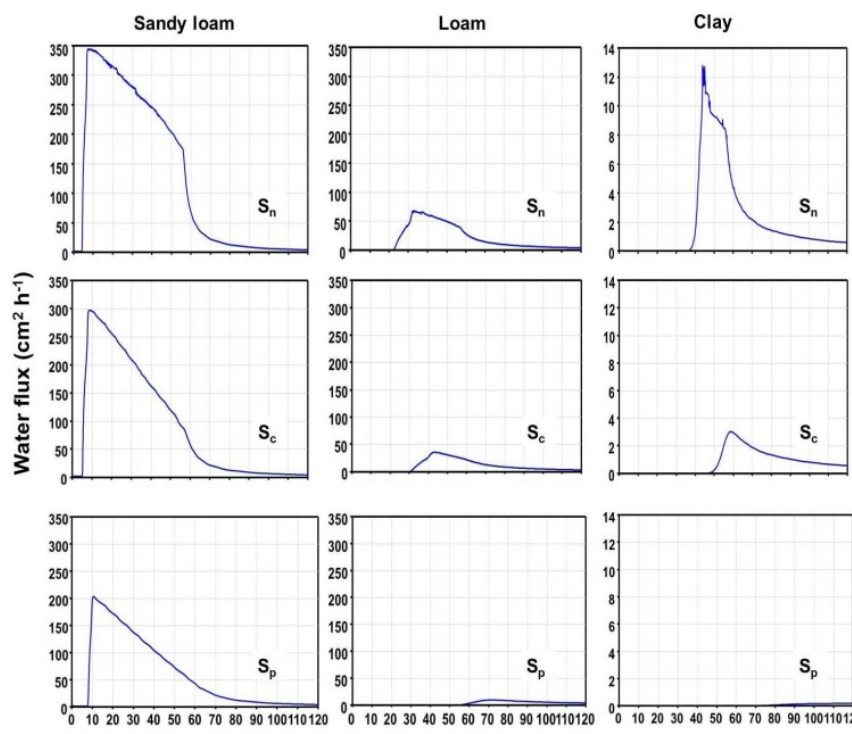

Time (h)
ig. 3. Water flux $\left(\mathrm{cm}^{2} \mathrm{~h}^{-1}\right)$ from the bottom of flow domain against time for sandy loam, loam and clay soils.

The figure shows that for sandy loam soil with soil management $S_{n}$ water flux increases rapidly to maximum of $348 \mathrm{~cm}^{2} \mathrm{~h}^{-1}$ within 7 hours of initiation of irrigation and then it decreases gradually. Whereas, for $\mathrm{S}_{\mathrm{c}}$ and $\mathrm{S}_{\mathrm{p}}$, bottom drainage flux reaches to $300 \mathrm{~cm}^{2} \mathrm{~h}^{-1}$ after 8 hours and 200 $\mathrm{cm}^{2} \mathrm{~h}^{-1}$ after 10 hours respectively. Thus, with soil management strategies not only water flux decreased but also there was delay in attaining the peak drainage flux. The decrease in drainage flux from bottom boundary is due to the soil compaction which decreased the soil hydraulic conductivity by reducing number of conducting macropores while the plastic sheet completely restricted the water infiltration from the furrow bottom. Similarly for loamy soil maximum drainage flux of $67 \mathrm{~cm}^{2} \mathrm{~h}^{-1}$ with $\mathrm{S}_{\mathrm{n}}$ decreased to $36 \mathrm{~cm}^{2} \mathrm{~h}^{-1}$ after 43 hours and $9 \mathrm{~cm}^{2} \mathrm{~h}^{-1}$ after 70 hours with $\mathrm{S}_{\mathrm{c}}$ and $\mathrm{S}_{\mathrm{p}}$ respectively. For clay soil, similar trend obtained with maximum water flux of $12 \mathrm{~cm}^{2} \mathrm{~h}^{-1}$ after 44 hours for $S_{n}$ which decreased to $3 \mathrm{~cm}^{2} \mathrm{~h}^{-1}$ after 58 hours and $0.2 \mathrm{~cm}^{2} \mathrm{~h}^{-1}$ after 112 hours with $\mathrm{S}_{\mathrm{c}}$ and $\mathrm{S}_{\mathrm{p}}$ respectively. The cumulative bottom drainage flux and reduction in the drainage flux due to soil management strategies are given in Table II.

TABLE II: CUMULATIVE WATER FLUX FROM BOTTOM AND DECREASE IN

\begin{tabular}{|c|c|c|c|c|c|}
\hline \multicolumn{6}{|c|}{ FLUX IN \%. } \\
\hline \multirow{2}{*}{ Soil texture } & $\mathbf{S}_{\mathbf{n}}$ & \multicolumn{2}{|r|}{$\overline{S_{c}}$} & \multicolumn{2}{|r|}{$\mathbf{S}_{\mathbf{p}}$} \\
\hline & $\mathrm{cm}^{2}$ & $\mathrm{~cm}^{2}$ & $\%$ decrease & $\mathrm{cm}^{2}$ & $\%$ decrease \\
\hline Sandy loam & 14930 & 11200 & 25.00 & 7465 & 50.00 \\
\hline Loam & 2340 & 1299 & 43.78 & 399 & 81.87 \\
\hline Clay & 245 & 100 & 60.0 & 3.00 & 95.80 \\
\hline
\end{tabular}

By compaction of the furrow bottom $\left(\mathrm{S}_{\mathrm{c}}\right)$, the cumulative flux reduced to $26.3 \%$ compared to that of with $\mathrm{S}_{\mathrm{n}}$. Tractor 
wheels or Eversman v-shaped wheel can be used for furrow compaction (firming). Also a decrease of about $50.0 \%$ in cumulative flux was obtained when $\mathrm{S}_{\mathrm{p}}$ was applied. In case of loamy soil, cumulative drainage water flux decreased $43.78 \%$ and $81.87 \%$ under $S_{c}$ and $S_{p}$ respectively as to that of with $S_{n}$. Also a decrease of $60 \%$ and $95.8 \%$ was achieved with $S_{c}$ and $S_{p}$ respectively for clay soil. There was obvious change in the trend of moisture content of the profile. This recommends that if plastic sheet is used water content in the soil can be kept similar to $S_{n}$ using only $31 \%$ of water. Furrow irrigation is considered water use efficient method of irrigation compared to the other conventional flood irrigation methods. Even then, it is not considered as water use efficient method of irrigation. Hence, there is always room for improvement of efficiency of furrow irrigation method. When furrow irrigation is used in combination with soil amendment strategies then Furrow method can be an encouraging method of irrigation.

\section{B. Nitrogen Leaching}

Nitrogen flux emerging from bottom of furrow of sandy loam soil for placements $P_{1}$ and $P_{2}$ is shown Fig. 4. It shows that cumulative nitrogen flux for $S_{n}$ with fertilizer placement $\mathrm{P}_{1}$, started after 5 hours of start of irrigation. Whereas, for $\mathrm{P}_{2}$, the maximum cumulative flux was $46 \mathrm{mg} \mathrm{cm}^{-1}$. Similarly, for $\mathrm{S}_{\mathrm{c}}$ and $\mathrm{S}_{\mathrm{p}}$ about $31.3 \%$ and $17.6 \%$ less nitrogen percolated with $\mathrm{P}_{1}$ compared to $\mathrm{P}_{2}$. For fertilizer placement $\mathrm{P}_{1}$, with $\mathrm{S}_{\mathrm{c}}$ and $\mathrm{S}_{\mathrm{p}}$ about $18.0 \%$ and $37 \%$ respectively less nitrogen percolated related to $S_{n}$.

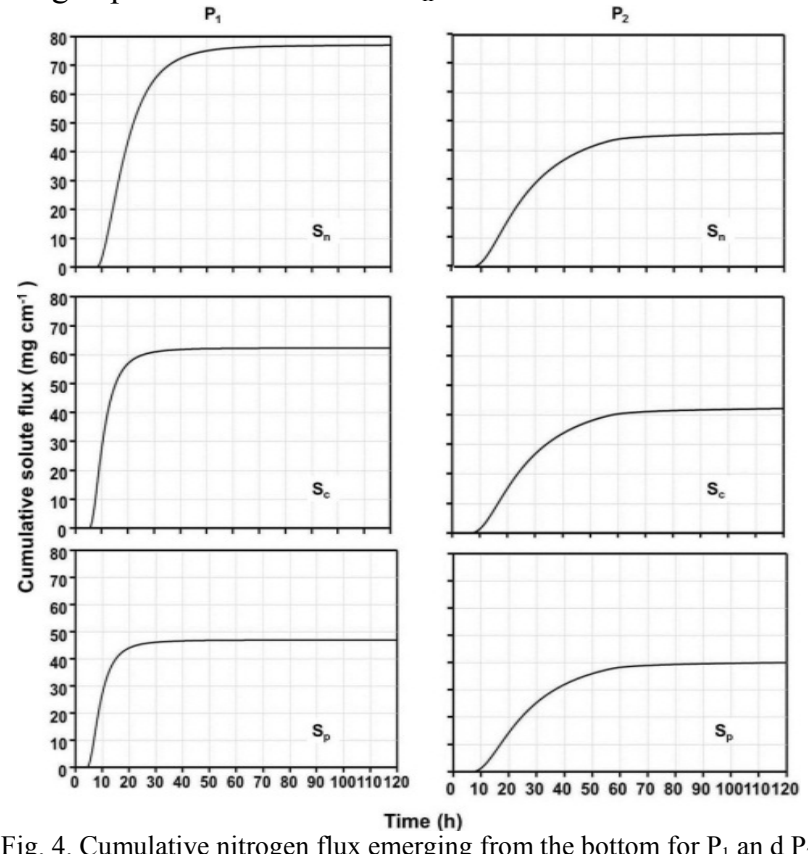

Fig. 4. Cumulative nitrogen flux emerging from the bottom for $P_{1}$ an $d P_{2}$

Cumulative nitrogen flux from bottom for loamy soil under fertilizer placements $\mathrm{P}_{1}$ and $\mathrm{P}_{2}$ and for clay soil for placements $\mathrm{P}_{1}$ subjected to considered soil management strategies is shown in Fig. 5. It shows that nitrogen leaching decreased $10 \%$ and $76.6 \%$ for loamy soil with fertilizer placement $\mathrm{P}_{1}$ implementing $\mathrm{S}_{\mathrm{c}}$ and $\mathrm{S}_{\mathrm{p}}$ compared to that of with $\mathrm{S}_{\mathrm{n}}$. Similarly leaching of nitrogen from flow domain reduced to $44.4 \%$ and $60 \%$ by using $S_{c}$ and $S_{p}$ compared with $\mathrm{S}_{\mathrm{n}}$ under placement for $\mathrm{P}_{2}$. When placement was changed from $\mathrm{P}_{1}$ to $\mathrm{P}_{2}$ nitrogen leaching decreased to $91.6 \%$, $94.4 \%$ and $91.7 \%$ with $\mathrm{S}_{\mathrm{n}}, \mathrm{S}_{\mathrm{c}}$ and $\mathrm{S}_{\mathrm{p}}$ respectively. About $94 \%$ and $98 \%$ reduction in percolation of nitrogen obtained by using $S_{c}$ and $S_{p}$ respectively in contrast to $S_{n}$ for clay soil with fertilizer placement $P_{1}$. From this it can be concluded that minimizing the direct contact flowing water with fertilizer reduces the risk of nitrate leaching to the groundwater.

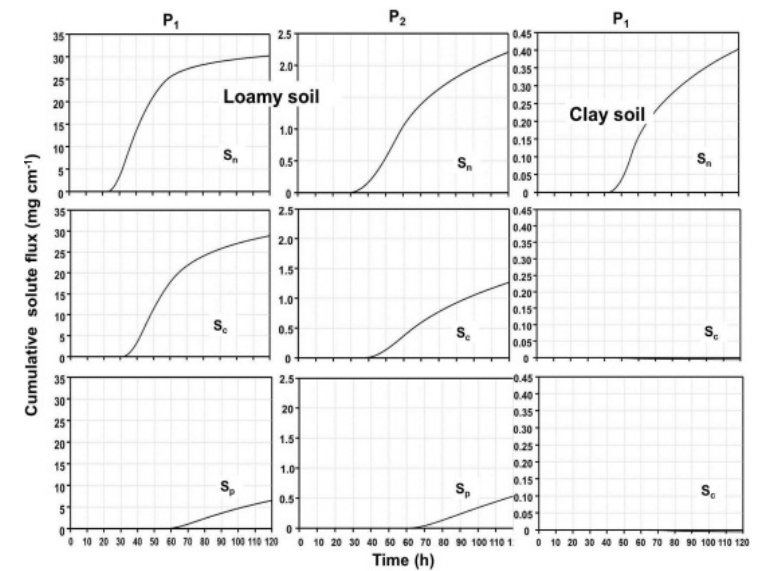

Fig. 5. Cumulative nitrogen flux emerging from bottom of flow domain

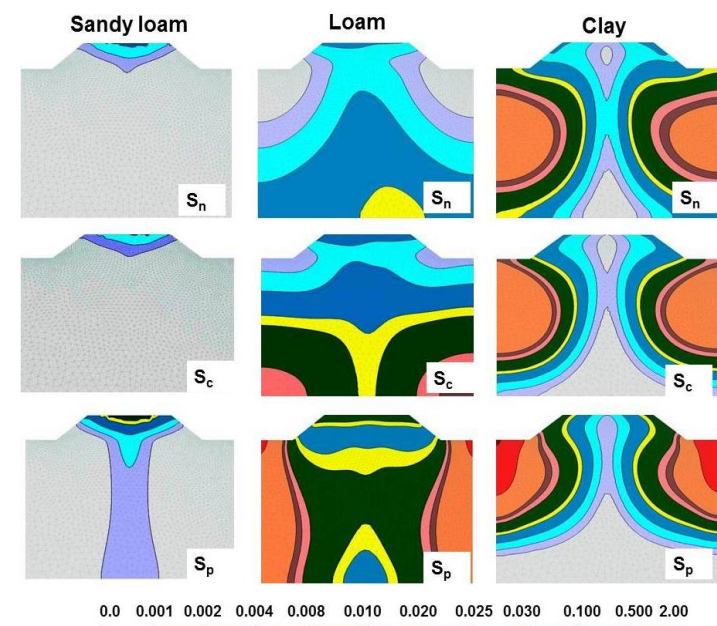

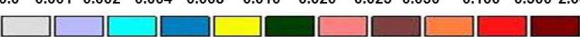

Fig. 6. Profiles of nitrogen concentration $\left(\mathrm{mg} \mathrm{cm}^{-3}\right)$ for placement $\mathrm{P}_{1}$.
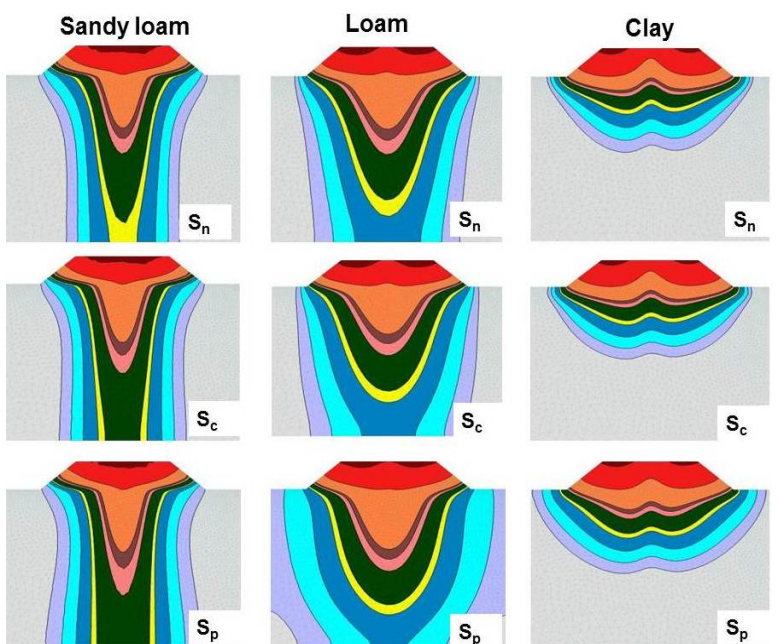

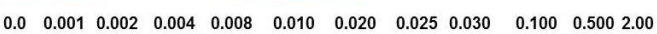
$\square \square \square \square \square \square \square \square \square \square \square$

Fig. 7. Profiles of nitrogen concentration $\left(\mathrm{mg} \mathrm{cm}^{-3}\right)$ for fertilizer placement $\mathrm{P}_{2}$.

Profiles of nitrogen concentration for fertilizer placement $\mathrm{P}_{1}$ under different soil management strategies are shown in Fig. 6. It shows that soil management strategies favour the 
staying of nitrogen longer in the flow domain. Concentration $\left(\mathrm{mg} \mathrm{cm}{ }^{-3}\right)$ for fertilizer placement P2 with different soil management strategies is shown in Fig. 7.

Nearly all nitrogen remains in the root zone in clay soil on the contrary for loamy and sandy loam nitrogen remains in the zone under surface.

\section{CONCLUSIONS}

The work given in this paper shows the outcome of fertilizer placements and soil management strategies on irrigation efficiency and nitrogen leaching from furrow irrigation system. Results obtained through computer simulations demonstrate that there are chances of improvement of furrow irrigation method with respect to water and fertilizer use efficiency. Our study shows that fertilizer placement in furrow affects greatly the quantity and time of nitrogen percolation below the vadose zone.

Risk of groundwater pollution can be reduced by placing fertilizer near top of the ridge. Results of the study showed that $15 \%$ to $99 \%$ of nitrogen can be hold in the vadose zone by adopting fertilizer placement $\mathrm{P}_{2}$. Whereas, by using soil strategies $\left(\mathrm{S}_{\mathrm{c}}\right.$ and $\left.\mathrm{S}_{\mathrm{p}}\right)$, about $10 \%$ to $98 \%$ of nitrogen leaching decreased. Savings of water from $25 \%$ to $60 \%$ are possible by compaction of bottom of furrow, which further can be enhanced from $50 \%$ to $95 \%$ with strategy $\mathrm{S}_{\mathrm{p}}$.

\section{REFERENCES}

[1] J. S. Angel, C. M. Cross, R. L. Hill, and M. S. McIntosh, "Soil nitrate concentrations under corn as affected by tillage, manure, and fertilizer applications," J. Environ. Qual., vol. 22, pp. 141-147, 1993.

[2] P. N. Rekha, R. S. Kanwar, A. K. Nayak, C. K. Hoang, and C. H. Pederson, "Nitrate leaching to shallow groundwater systems from agricultural fields with different management practices," J. Environ. Monit. vol. 13, pp. 2550-2558, 2011.

[3] R. J. Hayens, "Principles of fertilizer use for trickle irrigated crops," Fertilizer Res., vol. 6, no. 2, pp. 235-255, 1985.

[4] R. M. Waskom. Best management practices for nitrogen fertilization. Colorado State University Cooperative Extension and Colorado Department of Agriculture. Bulletin \# XCM-172. [Online]. Available: http://www.npscolorado.com/xcm172.pdf, 1994.
[5] EPA, "National Primary Drinking Water Regulations," United States Environmental Protection Agency, EPA Report 816-F-09-004, pp. 34, 2009.

[6] R. L. Shirley, C. H. Hill, J. T. Maletic, O. E. Olson, and W. H. Pfander, "Nutrients and toxic substances in water for livestock and poultry," Natl. Acad. of Sci., Washington, DC, pp. 37-38, 1974.

[7] J. T. Waddell and R. R. Weil, "Effect of fertilizer placement on solute leaching under ridge tillage and no till," Soil and Tillage Research, vol. 90, pp. 194-204, 2006.

[8] B. K. Wylie, M. J. Shaffer, M. K. Brodahl, D. Dubois, and D. G. Wagner, "Predicting spatial distributions of nitrate leaching in northeastern Colorado," J. Soil Water Conserv. vol. 49, pp. 288-293, 1994.

[9] C. M. Burt, A. J. Clemmens, T. S. Strelkoff, K. H. Solomon, R. D. Bliesner, L. A. Hardy, T. A. Howell, and D. E. Eisenhauer, "Irrigation performance measures: efficiency and uniformity," J. Irrig. Drain. Eng., vol. 123, pp. 423-442, 1997.

[10] J. S. Torres, F. Villegas, and R. Cruz, "Alternate Furrow irrigation of sugarcane," Proc. Int. Soc. Sugar Cane Technol., vol. 22, pp. 168174, 1996

[11] S. A. Clay, D. E. Clay, W. C. Koskinen, and G. L. Malzer, "Agrichemical placement impacts on alachlor and nitrate movement through soil in a ridge tillage system," J. Environ. Sci. Health, vol. 27, no. B, pp. 125-138, 1992.

[12] J. T. Waddell and R. R. Weil, "Effect of fertilizer placement on solute leaching under ridge tillage and no tillage," Soil and Tillage Res. vol. 90, pp. 194-204, 2006.

[13] T. H. Skaggs, T. J. Trout, J. Simunek, and P. J. Shouse, "Comparison of HYDRUS-2D Simulations of Drip Irrigation with Experimental Observations," J. Irrig. Drain Eng. vol. 130. no. 4, pp. 304-310, 2004.

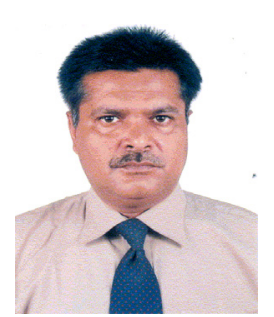

Altaf Ali Siyal is currently working as professor and chairman of the Department of Land \& Water Management at Sindh Agriculture University Tandojam, Sindh, Pakistan. In 2011, he got Endeavour Research Fellowship sponsored by Australian Government for conducting Postdoctoral Research at CSIRO-ATSIP, Townsville, Australia. During 2007-8, Altaf won Fulbright Fellowship to carry out research on "Water and solute transport simulation under conventional subsurface irrigation methods" at the USDA Salinity Laboratory in Riverside, USA. He completed his Ph.D. Degree in 2001 at the Cranfield University, United Kingdom on 'Maximising salt leaching efficiency of clay saline soils'. He earned his Master's degree in Irrigation \& Drainage in 1998 and Bachelor's degree in Agricultural Engineering in 1990 from the Sindh Agriculture University Tandojam, Sindh, Pakistan. He is particularly interested in Water Resources Management especially under arid conditions. 